\title{
Caste Politics and State Integration: a Case Study of Mysore State
}

\begin{abstract}
The subject of unification is as vibrant as national movement even after 58 years of a fractured verdict. More than to achieve a physical conjugation it was an attempt for cultural fusion. The aspiration for linguistic unification was a part of the national discourse. The movement, which began with mystic originations, later on turned out to become communal. Political changes during 1799 A.D. and 1857 A.D. changed the fortunes of Mysore state and ultimately led to its disintegration and became the reason for this movement. The concept of unification is akin to the spirit of nationalism, against the background of colonial regime assigning parts of land to different administrative units without taking into consideration the historical or cultural aspects of that place. Kannadigas marooned in multi lingual states experient an orphaned situation got aroused with the turn of nineteenth century. The problem precipitated by the company was diluted by British when they introduced English education. Though the positive aspect like emergence of middle class is pragmatic, rise of communalism on the other hand is not idealistic.

This research paper is designed to examine the polarization of castes during unification movement of Mysore State (Presently called as State of Karnataka, since 1973, which was termed Mysore when integrated) which came into being in 1956 A.D. Most of the previous studies concentrate on two aspects viz ideological discourse and organizational strategies adopted to gain Unification. The course of the unification movement and role of Congress party dominates such studies while some of them concentrate on the leaders of the movement. Other studies are ethnographical in nature. 'Community Dominance and Political Modernisation: The Lingayats' written by Shankaragouda Hanamantagouda Patil is a classic example. Mention may be made here of an recent attempt by Harish Ramaswamy in his 'Karnataka Government and Politics' which has covered almost all aspects of emergence of Karnataka as a state but communal politics during unification movement has found no place. 'Rethinking State Politics in India: Regions within Regions' is an edited book by Ashutosh Kumar which has articles on 'Castes and Politics of Marginality' where a reference is made to caste associations and identity politics of Lingayats, but the area of study is neighboring Maharashtra and not Karnataka. Though it contains two articles on Karnataka its subject matter doesn't pertain to this topic. One more important effort is by 'Imagining Unimaginable Communities: Political and Social Discourse in Modern Karnataka' where the author Raghavendra Rao thinks Karnataka and India as two
\end{abstract}


unimaginable communities and discuss primarily the founding moments of negotiation between the discourses of Indian nationalism and Kannada linguistic nationalism. It is more an intellectual history and throws light on nationalism in a colonial context.

Mostly studies concentrate on either the course or the leaders of the movement. Invariably congress as an organization finds place in all studies. But the blemish of such studies is a lesser concentration on activities of major socio cultural groups. The role of socio cultural groups assumes importance because of the milieu at the beginning of 20th century which annunciated a wave of social changes in the state. It is a known fact that the movement for linguistic state was successful in bringing a political integration of five separate sub regions but failed to unite people culturally. This concept of unification which is akin to the spirit of nationalism got expressed at the regional level in the sense of respect for once own culture, language and people. In case of Karnataka this expression had political overtones too which is expressed by some who fought for it (Srinivas \& Narayan, 1946 ). Most of the early leaders of unification movement (and for that matter even movement for independence too can be cited here) belonged to one particular caste, and with passing of time has led to the notion of domination of that caste over the movement. This paper tries to give justice in a limited way by giving legitimate and adequate recognition for those castes which deserves it and do away with misconceptions. Two concepts political modernization and social mobility are used. The later derives its existence from the former in this case. The data used here is primarily gained from news papers and secondary sources like books and interviews given by participants. No hypothesis is tested nor any theory is developed in this attempt but historical materials are examined in the light of modernity. The key problem discussed here is emergence of communal politics and the role of social groups in unification. Biases of regionalism, caste and class have been overcome by rational thinking.

Key words: Political integration, linguistic movement, political modernization, caste politics, communal politics, social mobility, middle class.

\section{Introduction}

The State 'Karnataka' occupies a position of prominence both culturally as well as politically in the history of India. It is the $8^{\text {th }}$ largest state in area and $9^{\text {th }}$ largest by population among Indian states. Present in the West-central part of peninsular India it consists of parts of Arabian Sea with coastal line, Western Ghats with thick evergreen forest, the parts of erstwhile Mysore state and a landscape of crystalline plateau. With its special geographical location, varied topography, colourful history and scenic beauty, numerous wildlife and rich tradition and culture, the contribution of the state to the union of India is unique. Apart from its historical contribution the State is in forefront of software revolution. Globalisation has helped the state to create ripples in distant American and European countries. In matter of culture \& tradition, in its sociology, religious $\&$ civic life, in its fine art $\&$ architecture, sculpture, painting \& music, indeed, even in its variegated \& magnificent 
Physiography, "Karnataka may well be an abridgement of India herself." (Srinivasa, 1924, p.16).

Karnataka has a glorious past. The country was rich charming and full of natural resources. It has a long and distinguished history. Economic prosperity along with peace was the key for the development in the field of literature, art and architecture, fine arts etc. The land is as ancient as the word 'Karnataka'. The ancient work to refer the land is 'Mahabharata'. Reference to this word is found in epics such as 'Ramayana' \& 'Skanda Purana'. Foreign Sources like Pliny and Ptolemy too has referred the word in their writings while giving details regarding the maritime activity of Karnataka with Western countries. The word was in use even before the time of 'Varahamihira' the great astronomer who mentions it in his 'Brihatsamhita' and 'Shudraka' in his 'Mrichhakatikam'(a Sanskrit drama).

The majority of the people in the region are of 'Dravidian' origin. Dravidians were the original inhabitants of Indian subcontinent and in Vedic literature they have been mentioned as 'Dasyus' and 'Rakshasas'. The antiquity of the State dates to the Paleolithic Age. Karnataka has a rich pre historic past.

Geographically, Karnataka is situated on the western edge of the Deccan plateau between latitude $11.31^{\circ}$ and $18.45^{\circ}$ North of the longitude $74.12^{\circ}$ and $78.40^{\circ}$ East. The area of the state is $1,91,791$ sq.km $(74,122 \mathrm{sq}$ miles). It is the eighth largest state in India. The latest population according to 2011 census is $6,11,30,704$. The number of Males in the population is $3,10,57,742 \&$ the numbers of females are 3,00,72,962. By population it is ninth largest state. Karnataka, one of the four states in South India, has 30 administrative districts and $5.83 \%$ of the area of the country. It is covered by Deccan Plateau to the West, Goa and Maharashtra in the North Tamil Nadu and Kerala in the South and Andhra Pradesh in the East. The state extends to about $750 \mathrm{~km}$ from North to South and about $400 \mathrm{~km}$ from East to West.

\section{Brief history}

In what are known as 'Pre Historic' times the land 'Karnataka' was part of the extensive forest region known as 'Dandakaranya'. It was inhabited by Dravidians who were migrants $\&$ subdued forests $\&$ hill tribes. For Aryans who had nomadic instincts the country appeared to be wild \& un cleared. The inhabitants appeared to be uncivilised. Though Aryans made up their mind to invade the country, 'Vindhyas' acted as an impediment to their venture. "For a long time 'Vindhyas' defied the Southern advance of Aryans, but even the 'Vindhyas' could not prevent them forever." (Srinivasa 1924, p.17). Amongst the earlier Aryans to cross 'Vindhyas' mention of sage 'Agasthya' \& 'Vishwamitra' are made in the literature of 'Sangama Period'. 


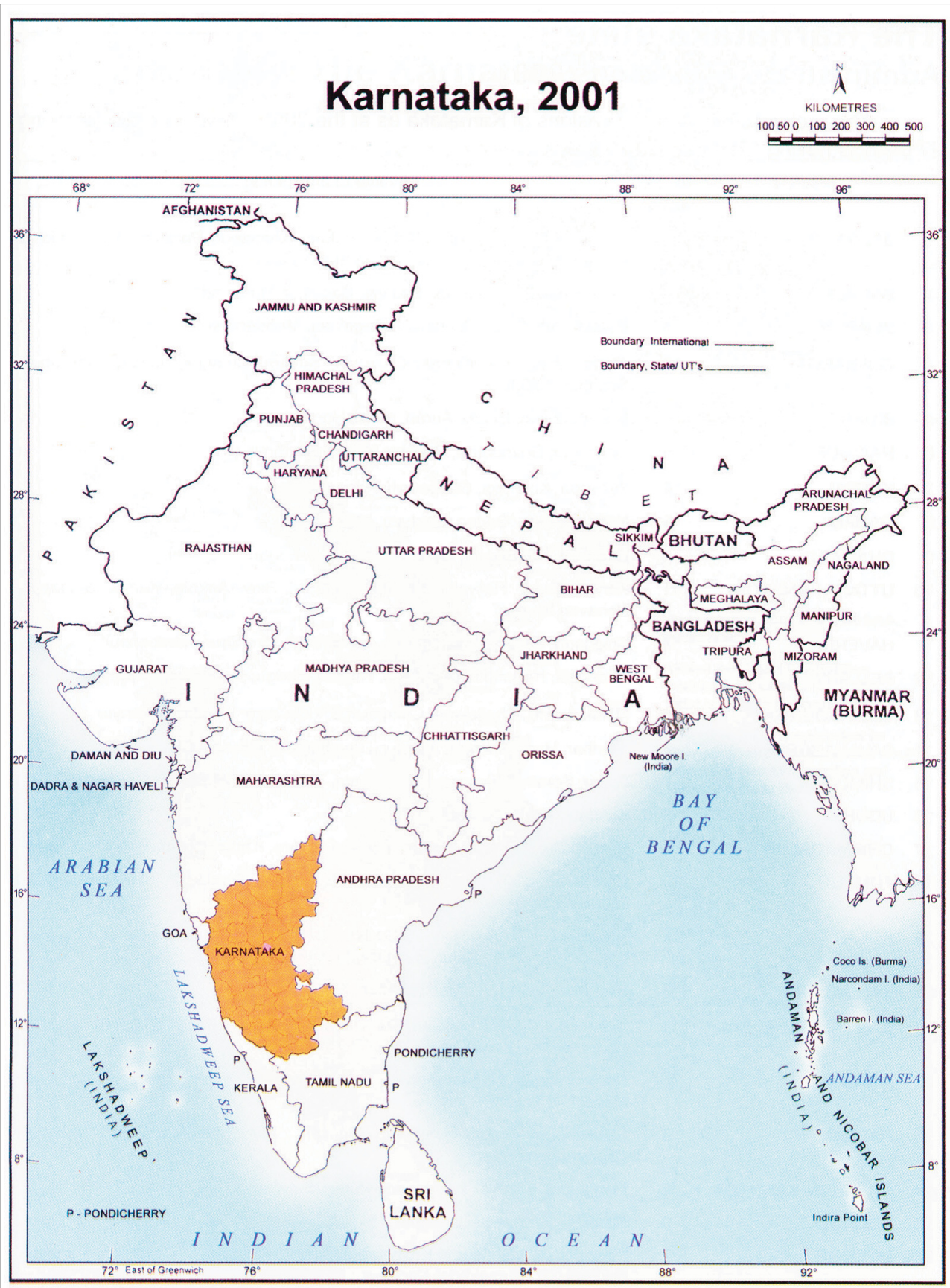

Map 1: Political map of Karnataka 
When they were constantly harassed $\&$ molested and were not allowed to perform their daily duties of life, 'Kshatriyas' of solar \& lunar dynasties descended here to protect them. This indirectly led to the unification of the country. Along with this the other result was also far reaching. At the beginning there was a cultural clash. Gradually the two cultures mingled \& led to a mix which is practiced even today. Viewed in the above perspective 'Aryanisation' was the most important event of 'Pre Historic' times. The process of 'Aryanisation' was completed in the State latest by fourth century B.C.

During the beginning of pre historic times 'Karnataka' is believed to be the part of Nanda's \& Maurya's. We are yet in dark regarding their political history in this part. But their rule can be testified by two different facts. Firstly 14 Rock edicts of 'Ashoka' (10 minor \& 4 major) are found scattered in various parts of Karnataka. Secondly according to confirmed Jaina tradition, the Mauryan king 'Chandragupta' of the pre-Christian period (c. 300 B. C) either Ashoka's Grandfather 'Chandragupta I' or his Grandson 'Samprati Chandragupta' is said to have travelled along with the sage 'Bhadrabahu', accompanied by the Sangha of his disciples, to 'Punnata' i.e. a part of Mysore, Karnataka and stayed in 'Kalbappu' at 'Shravanabelgola' for practicing penance. (Rice, 1984). The 'Kadambas of Banavasi' who established themselves during 345A.D and 'Gangas of Talakadu' were the first indigenous dynasties which ended the domination of 'Pallavas' to divide Karnataka amongst themselves. They succeeded 'Shathavahanas who were the earliest to establish a kingdom in South India taking advantage of the decline of Maurya's.

They were followed by 'Chalukyas of Badami' (c.540 to 753 A.D) who overthrew kingdom of Banavasi and subjugated 'Gangas of Talakadu'. They unified the State for the first time. This period may be termed as 'Golden Period' during historical times in the history of South India in general \& Karnataka in particular. Their famous ruler 'Pulakeshin II defeated 'Harshavardana' \& his grandson \& leaved tribute on North India. He conquered Gujarat \& appointed a viceroy at 'Vengi'. The famous Chinese traveller 'Hieun Tsang' visited Maharashtra which was the part of his kingdom. He also sent an embassy to Persia when Khusru II was ruling. It will be not out of context to mention here that the invincible army of the State was often referred to as 'Karnatabala'. An expedition was sent to 'Cambodia' when 'Vinayaditya' (681-96 A.D) the son of 'Vikramaditya I' was ruling. The same army defeated Arabs who tried to penetrate Gujarat. Soldiers from Karnataka were employed by the Pala rulers of Bengal. One such Kannada warrior founded the 'Sena Dynasty' of Bengal \& called themselves as 'Karnata Kshatriyas' and the other 'Karnata Dynasty' of 'Mithila' (modern Tirhath in Bihar) (A Hand Book of Karnataka 2008, p.61). Arab Visitor 'Suleiman' who visited the State during 851 A.D calls 
the empire as "One of the four great empires of the world." (Karnataka State Gazetteer 1982, p. vii).

They were followed by Imperial 'Rashtrakuta's who inaugurated one more glorious chapter in the history. They perhaps had to wait for a long time to gain prominence. An agricultural and martial community of ancient Karnataka is described in 'Kavirajamarga' the earliest available Kannada work as 'Nadavar's \& are referred to as "sons of the soil." (Mugali 1990, p. 37). These Nadavar's were the earlier natives of Deccan plateau. Nomadic at the beginning they adopted agriculture which made them not only leave their nomadic life but to learn defending their belongings. This led them to build forts and armies. They grew up in course of time and spread all over Karnataka, giving rise to small and independent kingdoms, striving for supremacy over each other. Of these 'Nadavar's mentioned in 'Kavirajamarga' of 900 A.D. (1-38 and 2-28) seem to belong to the original stock called as 'Rathika' or 'Ristika' in the Ashoka edicts. 'Rathika' or 'Rastrika' is very likely a Sanskrit rendering of 'Nadavar a Kannada word (Rastra meaning Nadu). These 'Ristrikas', who are spoken of as 'Rathis' and 'Maharathis' from before Christ are shown to be Kannada speaking and seem to be the ancestors of the 'Rattas', who rose to power and built up in later times the 'Rashtrakuta Empire' of Karnataka . The 'Pitinikas' i. e. 'Pratisthanakas' appear to have been the forefathers of the 'Shatavahanas', who ruled with 'Pratisthana' as their capital and who were the earliest to found an empire in Karnataka (Altekar 1967). 'Rashtrakuta' rulers like 'Dhruva' \& 'Govinda' III not only levied tribute to the rulers of Kanauj in Northern India but briefly occupied the place itself during 914-916 A.D. The same book 'Kavirajamarga' also describes the geography of Karnataka as 'land stretching from Kaveri to Godavari' (rivers).

By the time when Northern India was under the crises of Muslim invasions this part of India was quite under the rule of 'Hoysalas of Dwarasamudra' whose contribution in the field of architecture is unparallel. Northern parts of the earlier empire were occupied by 'Yadavas of Devagiri' while the Southern parts were under 'Hoysalas of Dwarasamudra'. Though the beginning of $12^{\text {th }}$ Century did not pose any problems, the frequent wars between the two dominate this period, weakened the military forces of both powers. The State was disunited \& paralysed which gave opportunity for Muslims under 'Ala-ud-din Khalji' to enter \& occupy Deccan. This not only changed the course of History but also the equilibrium of Deccan. Ala-ud-din Khalji was successful in defeating both Hoysalas \& Yadavas inaugurating the rule of Delhi Sultanate. The excesses conducted during their rule for about a century in general \& the religious \& foreign policies followed by them ultimately led to the foundation of 'the Vijayanagar Empire' during 1336 A.D.

Undoubtedly 'the Vijayanagar Empire' was the greatest dynasty to rule the state at any given point of time. German scholar Robert Sewell who was 
instrumental in introducing the empire to the modern world has written a book 'Forgotten Empire'. The opening sentence of the book in itself mirrors the achievement of the dynasty when he says 'It is really red letters day in the Annals of Indian history when Vijayanagar Empire came into being'. The empire became talk of the town with its fabulous wealth, glorious capital, heroic \& generous kings, their secular religious policies \& all round development of the State. Most of the rulers were diplomatic \& the empire became famous for its power, army \& trade. Above all keeping in mind the popular indignation of the subjects the empire unified the whole South India and acted as the saviour of Hinduism. They were followed immediately by 'Bahamani dynasty' (1347A.D) the founders who escaped to South India to escape persecution of Delhi Sultanate. This set them in direct clash with Vijayanagar Empire who had already vowed to protect the land from alien invasion. The story for next couple of centuries is that of the survival of the fittest in which the Vijayanagar Empire was successful in maintaining the integrity of the land. The empire crashed as a result of the battle of 'Rakkasa Tangadagi', or 'battle of Talikote' in 1556 under the leadership of 'Ramaraya'. But the torch of Vijayanagar empire was kept burning by the descendants of the 'Aravidu' line for about a century but with a lesser limelight. The history of Karnataka since then is a history of the spoliation of Karnataka by alien powers, struggling for supremacy and eager to extend their dominions. Although the Bahamini kingdom was weakened by being split up into five dynasties, unity of religion strengthened it and brought about the downfall of Vijayanagar. The 'Adil Sahi' kings of Bijapur grew more powerful than their allies and held all the Kannada territory, north of the Tungabhadra River. The descendants of the Vijayanagar line and the other smaller states tried at times to recover lost power but without lasting results (Mugali 1990).

The fall of Vijayanagar was a turning point in the history of Karnataka. Before the downfall of Vijayanagar Empire, Karnataka had reached a high pinnacle of glory in all matters which conduce to a greatness of a nation (Srinivasa 1924, p. 118). The fall of Vijayanagar gave opportunity for smaller feudatories for consolidation as well as expansion with in the territory. Mention here may be made of the 'Wodeyars of Mysore', 'Nayakas of Keladi' \& 'Chitradurga'. But the most powerful \& longest to rule the state were "the Wodeyars of Mysore" who ruled from 1399 to 1947 A.D. During initial stages their rule was confined to a small region around 'Srirangapattana' which later on became the nucleus of their long standing empire. Though they declared their independence by the time of 'Raja Odeyar' who ruled from 1578 to 1617A.D. \& secured 'Srirangapattana' (in 1610), their further rule was full of interludes first by 'Hyder Ali' (1752 -82 A.D) and his son 'Tipu Sultan' (1782-99 A.D). "The death of Tipu Sultan brought the indirect rule of the company in form of Wodeyars" (Muttanna 1990, p. 282). As 
Wodeyars proved ineffective in handling revolts $\&$ maintaining peace with in the State, the administration was taken over by the Company in form of 'Commissioners' from 1831-81A.D. for 50 years. This rule of the company at the beginning and the Queen later on brought with it lot of modernisation in the field of administration.

The direct rule of the colonisers began during 1831 A.D. Initially the company began with a senior $\&$ a junior Commissioner. As it created problems the system was given up and a 'Sole Commissioner was appointed in their place. 'Mark Cubbon' was the first sole commissioner during 1834 A. D. who left an indelible mark in the history of the state. When he took over the State its finance was in a very bad shape. The greatness of his rule can simply be understood by the fact that when he relinquished his office during 1861 A.D. he had not only cleared a loan of Rs 85 lakhs ( 1 lakh is equal to one hundred thousand) which was borrowed from 'Madras Presidency' for developmental works in the state, but also had created a reserve fund of Rs 40 lakhs. This could be achieved by providing infrastructure (for which loans were raised \& repaid) \& congenial atmosphere for trade. (He encouraged trade by abolishing tax on 440 items). 'Louie Bentham Bowring' who succeeded him carried the good work forward by bringing in administrative reforms which placed the state on a sound footing on which later developments could be placed. During these 50 years of commissioner's rule a mould was created from nowhere \& was given the form of 'State'.

Meanwhile the Wodeyars who had lost power were trying to regain power. With the help of 'Queens Proclamation of 1857' the kingdom was 'renidited' (In law, rendition is 'surrender' or 'handing over' of persons or property, particularly from one jurisdiction to another. Rendition can also be seen as the act of handing over) back to Wodeyars during 1881A.D who ruled until independence. Thus the indirect rule of the British began in the State. A resident was appointed \& limited power was handed over back to Wodeyars who ruled the State with the help of 'Dewans' till independence.

The period beginning from 1881 A.D. till independence turned out to the 'Golden period' for the history of Mysore state. Enormous development took place so rapidly that the state became a 'Model State' by the turn of the turn of the century. The story of development does not stop here. With the arrival of new century the 'Model State' was converted into 'Modern State'. Modernity was introduced into the state in real sense of terms. Along with materialistic development adequate measures were also introduced in the realm of society so that benefits of materialistic development reached all strata of society. This fact is endorsed in the words uttered by none other than the father of Nation 'Mahatma Gandhi' after his brief tour of the state exclaimed 'Ram Rajya' (a concept akin to Utopian state). Mention has to be made here of 'Dewan Rangacharlu' (The Word Diwan refers to the position of prime minister of the State) who introduced 'Legislative Assembly' 
way back in 1881 A.D (the first in the country), 'Dewan Sheshadri Iyer' who established first hydro electric station, 'Dewan Visveswaraiah' who initiated industrialisation (Industrialise or perish was his famous statement) $\&$ economic planning (for the first time in the country). It was the role of these Diwans with able support of Wodeyar kings as well the British were instrumental in this great leap forward.

The above crucial period (1831 A. D. to 1947 A. D.) offers a very tangible lesson not only for today's administrators but also for rulers. The insights that the period provides can be a guiding factor for anyone who wants to learn. It only then the study of history can be utilised \& appreciated. The momentum which was provided during the period could have been a launching pad for success after independence. But the opportunity was lost as the leaders of post independence failed to capitalise the initial momentum.

The state of Mysore was created on $1^{\text {st }}$ November by a parliamentary act integrating five Karnataka sub regions viz old Mysore, Bombay Karnataka, Hyderabad Karnataka, Madras Karnataka and Coorg. This was necessitated because of political importunity of Colonial masters who disintegrated the state recklessly without keeping in mind either the cultural or the linguistic pattern of the state. The advent of English education created awareness of nationalism and regionalism amongst this disintegrated and divested Kannadigas. Commencing at the turn of $19^{\text {th }}$ century it was a long march for them to achieve integration. The drama of communalism unfolded during the course of integration which consumed more time than expected because of tardiness of congress party which earlier had promised it and showed no urgency after it assumed power.

Geographically Karnataka is situated in the west-central part of peninsular India with an area of 19 million Sq miles. It is the $8^{\text {th }}$ largest state in area and $9^{\text {th }}$ largest by population among Indian states (with a population of 6.11 million according to 2011 census). In terms of area old Mysore is the largest sub region (69,165 Sq miles), followed by Bombay Karnataka with $(54,464 \mathrm{Sq}$ miles), Hyderabad Karnataka (35,687 Sq miles), Madras Karnataka (18,333 Sq miles), and Coorg (4,110 Sq miles) (Economic Development of Mysore -1956-69, 1970). Old Mysore dominated even on population front. But the core issue within the sub regions before integration was development and modernization. The demand for Kannada linguistic state "was part economical, part political, and part cultural" (Sheik 1997, p. 230). Old Mysore was way ahead with all round development (Along with physical development, Mysorians had legislature way back in 1881). "Hyderabad Karnataka was the most backward" (Rao 2010, p. 29). But in terms of natural resources, power and ports, the sub regions could add positive benefits to the ready available pile in old Mysore. 


\section{Why unification?}

The Unification movement is one of the other important and exiting events as the freedom movement in the history of the State. The idea of unifying people anchored in the mind of thinkers during the first half of this century when the idea of Nationalism was yet to catch the mindset of Indians. The division of Bengal during 1905 by the British and its repercussion acted as a trigger. Mahatma Gandhi the father of Nation had a chiseled perception of keeping away English (as a language) from Indians by achieving unification.

Besides emotional issue of language, the people who were disintegrated suffered manifold problems. The primary being the cultural domination of the locals who refused to consider these peoples as local's inspite of living in the area since time immemorial. Next in the queue was the discrimination in getting government jobs. As most of them were first generation English learners they had no option but to depend on a government job. The idea behind the clamour for unification was expression of desire to be included in the same political fold. Different sections of same linguistic groups wanted to merge under same administrative unit to discover their own identity.

It was the leaders of the movement who discovered, defined and designed the concept of unification. They tried to answer the question keeping in mind the prevailing situation as background and this was their answer: 'Unification has the objective of arresting the deterioration in the situation, bringing together the dispersed parts of the land and bringing about a kind of political unity. In other words, unification is a grand idea aiming at bringing them together under the same regional administration to bring about a sense of political integration (Govindaraju 2009).

The 'idea of Karnataka' has existed from the time of the earliest dynasties in the southern and northern Karnataka regions, but its historical 'unity' was broken in the $13^{\text {th }}$ century with the sack of Dwarasamudra by Malik Kafur. A striving for linguistic unity is traced back to the time of the Vijayanagar kings: the rule of the Bahamani sultans marks a break in the cultural continuity of the region (Alur, 1917 and Nair, Oct 1996 can be referred for language and culture of the State).Yet, although Kannada suffered blows from at least the 14th century, the actual territorial disintegration and the dismemberment of the Kannada people occurred with the defeat of Tipu Sultan and the start of British rule in 1799.

The disintegration of the State particularly post 1799 A.D. after the death of Tipu Sultan was in a way disorganized and without any planning. Keeping in mind the defense, economy and political consideration the British didn't consider race, language, history or geography during disintegration of the State. Thus people who came from different cultural and historical 
background could not unite mentally and led to sharp differentiation in their perceptions.

By the advent of advent of $19^{\text {th }}$ century the Indian people had adopted a variety of Western values and attitudes, of which one was Nationalism (Govindaraju 2009). The cultural renaissance which was witnessed at the beginning of $20^{\text {th }}$ century in the country paved way not only for the growth of regional languages but also for cultural unity. Culture became the mainstay to oppose colonialism. The voice of opposition to colonialism is first observed in the culture (Panikkar 1990). A new wave of consciousness among groups of people who spoke different languages swept through to identify them as a separate cultural entity. This consciousness ultimately led to the demand of linguistic States. The Congress party which led the freedom movement had recognized the importance of regional languages in imparting the spirit of nationalism amongst Indians. They had conceded to the demand of establishing regional congress committees (KPCC or Karnataka Pradesh Congress Committee, a regional congress committee for the State of Karnataka was established in 1920. In fact during its annual session at Nagpur during the same year the demand for regional committees throughout India were conceded).

The question of unification of Bengal province which is considered as an induction to National movement which culminated in liberating the country acted as a precedence for Alur Venkata Rao to excogitate the issue unification of Karnataka.

It is irony of the fact that the British who were responsible for the plight of these people acted as a catalyst (though indirectly) in demanding unification. They were responsible in unearthing the glorious history and tradition of Karnataka which created a sense of ego about their past amongst the sufferers which acted as a trigger in demanding unification. The missionary schools they opened not only adopted Kannada as the medium of instruction but also printed text books in that language. The printing of Canarese dictionary was the icing on the cake. Many Kannadigas followed this example and began promoting the language. Mention may be made here of Venkatarango Katti who established a press to print books in Kannada and among others Deshapande \& Shamarao Vittal who brought out simple books in Kannada language. "Deputy Chennabasappa a Kannadiga who was working in Bombay presidency fought to establish Kannada schools under his jurisdiction where a sizeable number of Kannadigas were present" (A Case for Karnataka Unification 1928, p. 26).

The idea of Nationalism which swept the nation during the same period dished up the idea of demand of unification. It was the influence of Bal Gangadhar Tilak the leader of extremist within Congress and who advocated and led revival of Hinduism in the country, had deep impact on people who craved unification. 


\section{How the process gained momentum}

Kannadigas especially those from Bombay presidency who went to Poona or Bombay for higher education observed the nationalistic intuitive amongst locals and could not escape from being influenced themselves. When they returned back it was natural for them to put such feelings into action. "Sometimes such actions were fierce in nature" (Sheik 1997, p. 216). Two streams of fall out of the fierce anger which is termed by Historians as 'Satwik anger' or nonviolent anger can be observed. One stream expressed itself in establishment of literary unions. Kannada Mitrakoota' (Union of Kannadigas) and 'Fourth Karnataka Club' were prominent establishments during the period while the second stream expressed itself in heightened literary activity. The net result of both the streams led to increased awareness on the language and thereby creating a nationalistic notion among the sufferers which acted as a centripetal agent.

The establishment of 'Karnataka Vidyavardaka Sangha' (a society to promote all round development of language) during 1890 at Dharwad by R. H. Deshpande was an important milestone in the renaissance of Kannada language in the disintegrated areas. Established to promote penchant for the language among other things (which finds mention in 'Vagbushana' a weekly journal of Karnataka Vidyavardaka Sangha.), Karnataka Vidyavardaka Sangha which is still active was the first to observe the notion of nationalism in renaissance of Kannada language and stood in forefront to promote history as a tool for nationalism. This establishment also became a stage to discuss unification.

During 1914 Alur Venkata Rao established Karnataka Historical Research Association to promote the cognizance of history. He also brought out a journal Ancient history under its aegis and held joint excavations in collaboration with archeological department. The idea behind all these activities was to enlighten people about their glorious heritage and thereby achieve unification of Karnataka. The year 1915 marks a cusp in the history of unification movement. It was during this year that the first literary conference was organized at Bangalore under the aegis of Kannada Sahitya Parishat (a literary body to support Kannada language established by the king of Mysore on the suggestion of his engineer turned Prime Minister Sir M Visvesvaraiah, can be loosely translated as 'Kannada Society of Literature' in English) which provided opportunity to assemble and discuss the plight and steps for unification of disintegrated Kannadigas for the first time.

To find a solution for the administrative and political problems of Kannadigas, 'Karnataka Sabha' was formed in 1916. It was the first political organization formally established for the purpose of launching the movement for Karnataka Unification. "Cuddapah Raghavendra Rao was the force behind 
'Karnataka Sabha', and it was he who kindled the aspiration for the creation of a unified Kannada State" (Govindaraju 2009, p. 15).

The holler of unification which originated from literary circles drifted towards political milieu in search of a permanent solution. Petitions and prayers became the order of the day for unification leaders. The home rule movement added fuel to fire (Referred to the efforts of Indian nationalists to achieve self-rule from the British Indian government notably Bal Gangadhar Tilak and Annie Besant). The regional conference organized during 1920 by the 'All Karnataka Unification Association' at Dharwad in the chairmanship of V. P. Madhava Rao not only brought Kannadigas from different presidencies together, but showed the perception of old Mysorians on the issue. The commixture of all above activities was the establishment of regional Congress committees all over India based on the language spoken, a demand conceded by the national party in it is a tacit tribute for the unification leaders who were in search for a political solution.

The annual Congress session of Belgaum in 1924 becomes important in backdrop of Unification Movement (Hallappa 1964). By that time Unification Movement had broaden its base which made even a political conference to discuss unification and pass resolution in this regard. The Zamindari (Landlords) conference which took place in 1926 at Coorg demanded that the province should be merged with Karnataka. "It became perennial to pass such resolution from now onwards. The silver jubilee of accession by the Maharaja of Mysore was celebrated in all Kannada areas including Mysore" (Sheik 1997, p. 222). This in itself was significant and showed the readiness of Kannadigas living outside to get unified under Mysore Kingdom.

The Motilal Nehru committee established by all party conference during 1928 gave a profound look to the question of unification after having deep discussion with a representative of regional congress committee. The report accepted the demand for unification without a second thought and also gave a detailed thought on pros and cons of such event. Pondering over the economic aspect of such an event the report states that 'economically the position of Karnataka is good. The provinces now under British presidencies are also rich...' This opinion cleared the economical fear from the mind of people.

The intensity of the unification movement was more in British presidencies than in Mysore state. Mysorians stood aloof inspite of continuous persuasion. Though historical reasons are attributed for this aloofness unification leaders differed in their opinion. Diwakar R.R. a unification leader who later on became a central minister opines this as a political aspect. Kannadigas present in British presidencies even doubted the aim of Kannada Sahitya Parishat (Kannada Society of Literature) in bringing about unification. Though the general tendency of Mysorians was to stay aloof in case of Unification, press 
and certain individual's whole heartedly supported Unification. Scholars attribute on more technical reason. The political relationship between Congress of Mysore and that with Congress at various presidencies was not harmonious. This might have reflected in their aloofness to support unification. Govindaraju C.R. a Professor at Kannada University, Hampi subscribes such an opinion.

To a question whether unification movement was importance or the national movement, we find assorted views. The importance of the question has to be understood because of the peculiar situation that existed in Karnataka wherein unification movement preceded the national movement. Most of them are of the opinion that national movement was more important while the people who suffered believe in the opposite. When the situation that prevailed in the parts where these sufferers scattered it was not much different from the situation that prevailed under colonial regime. Under such circumstances the spirit of unification movement was as important as that of national movement.

\section{Caste denomination in the sub regions}

\section{Old Mysore}

The region was dominated by Vokkaligas who constituted $20.54 \%$ of the population (The Backward Classes Commission Report 1956). Basically into agriculture they were slow in adopting modern education. But their middle class leaders were successful in politicizing their caste at the same time when the other major castes were doing so (Mohammed 1966). Historically Vokkaligas did not posses strong sense of cultural identity with Kannada linguistics. Lingayats constituted the second largest group with $15 \%$ of the population. Along with the modern education, they had the strong sense of cultural identity with Kannada linguistics in which the Vokkaligas lacked. "Lingayats were more militant in religious culture amongst other socio religious groups" (Rao 2010, p. 33). Brahmins were highly educated but less organized politically. Moreover they were divided based on their native states. A clear demarcation could be observed and mostly it was Madras Brahmins and Andhra Brahmins. Local Mysore Brahmins were against these groups. But generally Brahmins were not only identified with Kannada linguistics, but also with literature, both historical and modern. They were less militant religiously and readily accepted modernization. Muslims constituted around $10 \%$ of the population with a small middle class. The Harijans constituted around $18 \%$ of the population. Lack of education, leadership and support neutralized their strength. Jains and Christians constituted $1 \%$ of the population. Both of them were well educated but made no impact on the subject of our study. Culturally the people of this region were refined and distinct. The 
unifying factor for the masses irrespective of their castes was the kingdom and the king himself.

\section{Bombay Karnataka}

The then prevailing socio-economic conditions in these areas was in fact, quite different from that of the erstwhile princely state of Mysore. "Lingayats dominated the region with $28 \%$ of the population. This numerical superiority was fortified by strong group identity, rooted in history" (Rao 2010, p. 29). They were the first to challenge the Brahmins within Congress and national movement. Brahmins constituted $4 \%$ of the population and were most urbanized group. Infact Brahmins were in the forefront of both integration as well as national movement. Intermediate castes a classification existed under Bombay Presidency which is not found in Old Mysore represented 18\% of the population but were made up of number of small castes in which Marathas were dominant. The presence of Vokkaligas was negligible and hence had no impact in the region. Same was the case with Jains and Christians. Muslims constituted $10 \%$ of the population. Harijans constituted around $10 \%$ of the population. They were an amalgamation of 38 castes and were educationally and politically backward. The only integrating factor amongst various castes in the region was the language and culture which was akin to Maharashtra.

\section{Hyderabad Karnataka}

The situation here was entirely different as no Hindu dominated the sub region which was under the rule of Nizam. Lingayats constituted $30 \%$ and Brahmins about $4 \%$ of the population had no reasons to be on opposite side as Muslims appropriated all important posts. Harijans and intermediate classes represented $20 \%$ and $10 \%$ respectively but had no voice. Culturally they were akin to the people of Bombay Karnataka.

\section{Madras Karnataka}

This sub region presents a totally different picture in all aspects. Geographically it consisted of two districts which were diametrically opposite in every sense. South Canara was a coastal district while Bellary was plain. While Lingayats dominated in Bellary there was no trace of them in South Canara. The culture of Bellary was influenced by Andhra while that of South Canara was similar to Kerala. The spoken language and their culture too differed as the mother tongue of people of South Canara is Tulu while that of the people of Bellary is Telugu and Kannada. Some scholars, notably Raghavendra Rao K consider that this was the weakest of all sub regions as it was split after unification in 1956 there by loosing its identity at present times.

\section{Coorg}

Coorg presents a curious case amongst all sub regions. Coorg was 
independent State (C type) untill reorganization. It was the smallest of the entire sub region and was special in the sense that a different culture, geography and language existed there. No majority castes of other sub regions had substantial presence here. The Kshatriyas who consists $45 \%$ of the population are the dominant caste. No internal threat to their dominance exists as they are divided only into two sub castes of unequal proportion. The strength of the caste is not neutralized by any serious sub caste split (Sathyan 1965). Brahmins, Lingayats, Vokkaligas, Muslims and Harijans existed here as a numerically small groups to make any impact. One more specialty of the area was a minor attempt of secession after independence which was intracaste, personal factionalism and ideological conflict with in congress during 1951-52 assembly elections for Coorg legislature.

From the above discussion it is very clear that only two sub regions Old Mysore which was the nucleus of the wood be state and Bombay Karnataka the cradle of linguistic unification are important for our study.

\section{Hypothetical outlook}

The literature is dominated by American political scientists notably Lloyd, Rudolf and Myron Weiner and Rajni Kothari. Their premise is based on the paradigm that caste as a dynamic variable is the dominating factor in the process of political modernization. The paradigm is not denied but in case of Mysore state the role of class structure is overwhelming. Hence an attempt is made here to study caste politics of Mysore pertaining to linguistic movement within emerging class structure. Brahmins, Lingayats, Vokkaligas are the castes studied while it is the emerging middle class which played a pivotal role. This study is therefore the study of castes with a middle class structure. A study holds that caste politics emerged historically with the growth of urban middle class in Mysore (Rao 2010). Brahmins, who first understood the potential of English education which was introduced during mid 19th century, overwhelmingly embraced it, which led to the beginning of emergence of middle class. Others though slightly late followed them as it was a passport to bureaucracy. By the decade of 1930 almost everybody understood its potential, is substantiated even by a conservative document like census report which states '... caste consciousness has greatly strengthened during the decade----Hope of obtaining employment at the end of school or college has given great impetus---- ' The Middle Class, though small and mostly confined to Brahmins provided leadership and organizational skills to both linguistic and national movements (Anil 1968). This process gradually evolved and was adopted by other castes and by the end of $19^{\text {th }}$ century a formidable middle class had arrived in Mysore. 


\section{Evolution of communal politics}

Theoretically speaking evolution of caste politics takes place in three stages. They are:

1. Primordial stage.

2. Unitary or neo pluralistic stage.

3. Fragmented or individualistic stage.

\section{Primordial stage}

The characteristics of this stage are low level of modern education, low social mobility, low or no political participation. Even if such things are found, it is limited to a very few who are rich. Social reforms for the material benefits of the castes are extracted from the rulers. Caste groups in this stage are yet to be polarized. There are virtually no leaders and even if anyone is found he faces no challenge. Leaders try to bring cohesiveness within the caste by providing educational opportunities, training and jobs. These leaders put community interest over self interest as they face no challenge for their leadership. At the end of the period politicization of the castes begin.

\section{Unitary or neo pluralistic stage}

During this stage social mobility increases and we find the emergence of urban middle class. Castes try to discover themselves under changed circumstances. This leads to competition amongst them in demanding favours from the rulers. Political competition amongst various castes intensifies. It also leads to increase in power struggle amongst its leadership. Political scientists call this as golden period for communal politics. Politicization of the castes continues but it is not high.

\section{Fragmented or individualistic stage}

This stage is characterized by increase in social mobility. This naturally leads to the intensifications in atomization and individualization of community interests and identity. Two more important things happen. One is over politicization of castes. The other is intense struggle for leadership within the castes. The perception of leaders too changes from country towards self. Intense competition within makes self oriented politician turns his attention either towards sub castes or a broader ideology, party, organization or class to keep his political control intact. This leads to decommunalisation by those leaders.

\section{Story of unification and role of Congress party}

The fall of Tipu Sultan (1799 A.D.) which led to distribution of spoils disintegrated his empire into four parts. The central part consisting Mysore was returned to Wodeyars, Northern parts were given to Marathas and Eastern 
parts were given to Nizam of Hyderabad while the company retained Southern coastal areas. They were later termed as Old Mysore, Bombay Karnataka, Hyderabad Karnataka, and Madras Karnataka respectively. This was the root cause of unification movement. Congress had no regional unit within the state till 1920. "The eight hundred strong contingent led by Cuddapah Raghavendra Rao was successful in convincing Indian national congress for a regional congress during Nagpur session" (Sheik 1997, p. 221). The Nagpur session of Congress in 1920 accepted the principle of linguistic provinces and divided India into 21 linguistic congress provinces which resulted in Karnataka Provincial Congress Committee (KPCC) coming into being with Gadag as its headquarters. Its jurisdiction spread over the entire Karnataka including the princely State of Mysore. The Belgaum congress session of 1924 the only to take place on the soil of Karnataka and the only one to be chaired by Gandhi, discussed both unification and national movement. With a promise that unification would be done after attaining freedom, the movement was put to backburner and the leaders engaged themselves with national movement. "The leaders took care that the demand for unification did not override freedom movement" (Govindaraju 2009, p. 1).

Though the Indian National Congress accepted the principle of linguistic reorganization of the British provinces as early as 1920 A.D at its famous Nagpur annual session \& acted immediately by applying it to its own organization it forgot the promise and engaged itself in buying time after independence. The tardiness of congress party with regards to linguistic politics in general and unification movement in particular was universal once it came to power. This has to be understood in such a background that the same party was in forefront of both the constructs earlier. Now it was left to the people of sub regions who fought and forced congress for unification, wherein the communal politics is exhibited. The re-drawing of state boundaries to correspond with linguistic regions has been a cornerstone of the policy of India's ruling Congress Party since 1921, to some extent because (as is now frankly admitted) "it was a useful club with which to beat the British" (Marshall 1956). But they failed miserably once the country got its independence and Congress saddled itself at Delhi. This has been accepted by none other than Mr. Kunzru who was member of commission for Unification of states in India when he said that 'no more complex and important problem has con-fronted the Government of India since independence than that of linguistic regionalism, and probably none has been handled more ineptly' when he spoke in the Rajya Sabha (upper house) and as reported by the English daily The Hindu (Madras), 3 May 1956.

An obiter dictum may be made here with reference to communal politics of the State. The turn of the 20th century, brought not only modernization, but with it, some revolutionary changes. The new milieu provided right environment for evolution of communal politics. With the influence of some members of the ruling family, an organization 'Praja Mitra Mandali' was 
established in 1917 by C.R. Reddy. This led to the birth of Non Brahmin Movement within the State. Seeds of Non Brahmin Movement elsewhere were sowed by Satya Shodhak Samaj of Jotirao Phule in 1873 but the actual movement began with establishment of Justice Party in 1916 in Madras province. Praja Mitra Mandali demanded more opportunity for non Brahmins in government service as against the monopoly of Brahmins. The position of the Brahmins in government service was mainly due to their high rate of literacy and fluency in English. English was the key to enter government service. By 1920 the movement took a political colour supported by the political reforms announced by the Montague-Chelmsford Commission and the subsequent grant of adult suffrage. But ultimately Praja Mitra Mandali failed to achieve the object of its establishment and proved that it is in line with other organisations (Nagaraj 1993). The author fetchingly refers to the conflicts for minor issues within Praja Mitra Mandali, failure in its goal of development of backward classes, indulging in opportunistic ideology and goes on to refer ' a rat race to join the ranks of clerckdom' sacrificing ideology.

The Lingayats in the Mysore sub region, who were exposed to the forces of modernization at the turn of the century made serious attempts to compete with Brahmins for bureaucracy. The only sub region where the movement was inactive was in Hyderabad Karnataka region because the Muslim majority there forced cooperation between Brahmins and others.

\section{Communal politics in Mysore}

"The end of $19^{\text {th }}$ century is taken as a chronological baseline for the evolution of communal politics in Mysore" (Rao 2010, p. 198). It should be noted here that the conceptual framework discussed above is applicable to all Castes. But they evolve through these stages during different time frames. It has been observed that advanced groups compete amongst each other while curiously enough less advanced groups compete as well as collaborate with each other. Discussion of dominant castes with reference to topic above is done individually so as to present its role clearly and visibly. It also gives a full understanding of communal politics.

\section{Lingayat communalism}

The numero uno of the population in modern Karnataka, Lingayats were prime movers of linguistic movement which was conceptualized, launched and pioneered by Brahmins. Comparatively a new religion (founded in $13^{\text {th }}$ Century by Basaveswara, a minister under Bijjala and also called as Veerashivas) which was protestant in nature, were ferocious in achieving unification as they were the prime beneficiaries of it. They were the dominant caste in Bombay 
Karnataka where "a distinctive Lingayat communal politics evolved" (Rao 2010 , p. 175). In this case untill the decade of 1930's the community passed through the first stage (The primordial stage) where we find the interest of the community was preferred and efforts for their education, jobs was predominant and no leadership struggle witnessed. The early leadership of the caste was more 'community oriented' than national oriented or region oriented and it also tended to be non political and pro British'. During 1920's Lingayats supported anti Brahmin movement but the nature differed according to sub regions. In old Mysore they collaborated with Vokkaligas and later with Muslims while in Bombay Karnataka they were dominant. By the decade of 1930's they entered the second stage (The unitary or neo pluralistic stage). Here the community was more politicized as the leaders were found participating not only in national movement and linguistic movement but also used infiltration tactics in every field to oust the Brahmins from Congress and challenged their leadership in linguistic movement. It was Lingayats who politicized the Karnataka ideology in terms of communal and linguistic politics while it was Brahmins who politicized it as a mystic aspect for unifying people. Their intelligentsia put effort to promote Lingayatism in cultural field by evoking historical literature. Thus they exhibited communalism by trying to break the monopoly of Brahmins in all fields. It was such an open communalism that non Lingayats feared of their dominance in the unified state can be gathered by the following utterance that the unified Karnataka province would be a 'Lingayats Province' as verbalized by Karanth G.K. an active unification leader and Congressmen. Even their religious heads stepped in to promote their cause (Rao 2012). Above all leaders were impatient with other castes and started accusing them on false grounds.

During the same time in Old Mysore Lingayat communalism was in a different mode. Instead of open communalism as in the case Bombay Karnataka they had collaboration with Vokkaligas and Muslims and competed constitutionally against Brahmins in legislature. Here their communalism was not as fierce as in the case of Bombay Karnataka. A peculiar situation developed because of their policy. Not interested in open confrontation with other former collaborators, the Lingayats here tended to be friendly with Vokkaligas (who were opposing unification in fear of loosing their domination to Lingayats in unified State) but at the same time endorsed unification as a part of party strategy. It is believed that Lingayats were not ready to exhibit their communalism openly and invite the wrath of Vokkaligas put the onus on the party. Gradually more communal of them drifted away and formed 'Praja Party'. Earlier they had collaboration with Vokkaligas and Muslims to form 'Praja Mitra Mandali' a regional party while the moderates remained in Praja Mitra Mandali (a party of Non Brahmins). Thus the alliance was broken and the reason being unification. Now they exhibited open communalism and went even to the extent of "reaping the benefits of Vokkaliga factionalism (Rao 2010, p. 184) Overall Lingayat communalism 
in old Mysore was passive and could not have much impact as their counter parts in Bombay Karnataka.

By 1946 the Lingayats had gained control of Congress, unification movement and other institutions through the process of infiltration. The arrival of democratic institutions with independence helped them further to gain control as they enjoyed majority. Now they entered the third stage of communal politics (The fragmented or individualistic stage) where we observe considerable individualization which led to clashes among various Lingayat groups within the organization in which they had gained control through infiltration. Personal interest came to forefront while organizational interest took backseat. Clashes within Lingayats to gain control presidentship of Congress Party and Chief ministership may be mentioned here. Clashes were even reported in their premier institution 'Karnataka Lingayat Education Society' which was established to educate their Castemen. Modification of communal tactics and intercaste bargaining and coalition took place.

\section{Vokkaliga communalism}

The last of the dominant communities of the State, Vokkaligas were numerically superior only in Old Mysore sub region and had negligent presence in other regions. The community was late in availing educational benefits and thus their middle class emerged slightly later. They had many similarities and differences with Lingayats in respect to communal politics. Their communal politics was as ferocious as that of Lingayats, but restricted to only Old Mysore region. They too came to prominence with anti Brahmin movement like Lingayats. They were more communal with regards to their community than Lingayats which can be proved by the fact that they had established their Community Organisation way back in 1906 A.D. in Bangalore. Like Lingayats they too used the tactics of infiltration within congress as a part of communalism. But their identity in linguistic and historical culture was the weakest in the State.

Inspite of a weak linguistic culture the Vokkaligas were forced into the movement by the influence of Lingayats of Bombay Karnataka. But the force was not a choice but compulsion. The Vokkaligas were to loose majority in a unified state against Lingayats, which made them to oppose unification and fight to retain separate identity for Old Mysore. By infiltration tactics Vokkaligas gained upper hand in Congress and had formed the government after independence. By this time the community was going through third stage of communal politics (The fragmented or individualistic stage) where factionalism developed between Mr. Reddy and Mr. Hanumanthiah (respectively the first two chief ministers of Mysore). The infighting was more personal than ideological. There was no community consciousness during the period. The contest was won by Mr. Hanumanthiah 
faction who replaced Mr. Reddy for chief ministership. This led to the development of peculiar situation wherein Hanumanthiah fearing the loss of communal support half heartedly sided unification to stay in power as Congress party was for unification while his opponents the Reddy group openly opposing it. Thus linguistic issue got converted into communal political issue. Thus we find an uncharacteristic state of affair where in a fusion of sub regionalism and communalism in Vokkaliga Politics. With the ouster of Mr. Hanumanthiah in 1956 the threat to integration was removed. Though they failed in their communalism their effort in this front acted as an impediment in naming the new State as Karnataka which the Unification leaders wished (it was only in 1973 that their wishes were fulfilled). When compared to Lingayats, Vokkaliga communalism was less aggressive as even overwhelming threat of loosing power after unification did not bring any compromise within the factions.

It is interesting to note a point made by James Manor who is considered as an authority on Mysore politics. Lingayats and Vokkaligas at some stage ( $2^{\text {nd }}$ decade of this century) had unified under the banner of non Brahmin movement influenced by the milieu of Madras. Their attempt to open administrative structure failed because of the nature of government in Mysore was different and hence to gain upon the influence to control the higher ups they used a different approach of "gaining the ear of Maharaja" (Manor 1975, p. 138).

\section{Brahmin Communalism}

Brahmins present a nosy case in communalism during unification movement. Contradictory to the general perception that they are more communal they played no part or a minor part in communal politics during integration. They were the first to take advantage of English education during mid $19^{\text {th }}$ century and started to migrate to new urban centers which also mark the beginning of rise of urban middle class. Most of early unification leaders belonged to the community. Alur Venkata Rao the Kannada 'Kula purohit' or Archpriest of Kannada (title given by Government of Karnataka) evolved the concept of 'Kannadatva' meaning Kannadaness, gave emotional reason for unification. It is also interesting to note that he took the help of History to brace dormant Kannadigas belonged to this community. The early Congress leaders were also Brahmins and they were responsible to plant the ideology of linguistic integration within Congress. By the decade of 1930's, the period under consideration their influence in the kingdom of Mysore was over. Political scientists and historians signalize infiltration tactics from other castes particularly Lingayats and rise of middle class in other communities were the reasons for their decline. Ideally they had little economic power. Numerically their strength was too small to wield political influence. The period from mid $19^{\text {th }}$ century till the decade of 1930 's was their golden period. 
"Though they themselves did not develop communal politics, Brahmins inspired the communal politics of others in the region" (Rao 2010, p. 198). This narrates the whole story. Though leaders in the Bombay Karnataka region did protest communalism against the community, no such protests are observed anywhere outside the region. Hence after the beginning of communalism Brahmins lost leadership both within congress and linguistic movement. Their numerical strength (around $5 \%$ of total population) was the major reason for their decline. The conditions of mass and democratic politics that were emerging in the period placed the community at a clear disadvantage. The only way out was to challenge Lingayats supremacy by building a coalition with Vokkaligas and other intermediate castes which they did not. Contemporary leaders felt that Brahmins at that time failed to grasp the long term implications of Lingayat Communalism. When we apply the theory of evolution of caste politics to Brahmin community by the end of $19^{\text {th }}$ century, they were in their third stage of evolution (The fragmented or individualistic stage). It was fragmented and was individualistic. By 1940's the community leaders lost interest in linguistics reorganization. This can be proved by the fact that only one leader from community was selected as minister in the first two ministries of independent Mysore State. Great contemporary leaders like Diwakar, Datar and Karmakar found no place in regional politics. After independence there was increased regionalization of politics and dominant castes took over regional politics. By 1947 the community leaders lost the race virtually to Lingayats and Vokkaligas. By the discussion it is very clear that Brahmins did not indulge in communal politics like other communities.

\section{Conclusion}

Thus it is evident that communal politics played a major role in unification movement. Different caste groups had different intensities. Linguistic politics had different effects on different communal groups. In some groups it was at its escalated while in some it was nil. The direction of escalation too was different. In case of Lingayat communalism it was towards integration while in case of Vokkaligas it was towards separatism. "In case of Brahmins it produced no structured communal Politics" (Rao 2010, p. 202). The phase of communalism grew with Independence at sight as communal castes were in a rat race to grab political positions. It is also clear that with this communalism came political modernization. Lingayats and Vokkaligas generated communal politics in response to challenges of modern political systems like democracy after independence. This communalism became a medium for those castes which were lagging behind to get integrated with in modern political culture. But the role of urban middle class is core for all developments. 


\section{Reference}

(n.d.). 1928. A Case for Karnataka Unification. Dharwad: Karnataka Unification Sabha and Karnataka Pradesh Congress Committee.

A Hand Book of Karnataka, 2008. Bangalore: Government of Karnataka.

Altekar, A. S., 1967. The Rastrakutas and their Times. Poona: Oriental Book Agency.

Alur, V. R., 1917. Karnataka Gatha Vaibhava. Dharwad.

Anil, S., 1968. The Emergence of Indian Nationalism. Cambridge: Cambridge University Press.

Bureau of Economics and Statistics, 1970. Economic development of Mysore, 195669. Bangalore: Government of Mysore.

Diwakar, R. R., 1956. The Story of Karnataka Unification. Hubli.

Govindaraju, C. R., 2009. Movement for United Karnataka: Cultural Dimensions. Hampi: Kannada University.

Hallappa, G., 1964. History of Freedom Movement in Karnataka: Vol 2. Bangalore: Government of Karnataka.

Karnataka State Gazetteer, 1982. Bangalore: Government of Karnataka.

Manor, J., 1975. Princely Mysore before the storm: The state level political system of India's model state 1920-36. Modern Asian studies, 91. p. 138.

Marshall, W., 1956. The Politics of States Reorganization in India: The Case of Bombay. Far Eastern Survey, 25(9), pp. 129-143.

Mohammed, I., 1966. Mysore Aga Mattu Iga. Mysore: T Venkannayya Memorial Publication Series.

Mugali, R., 1990. The Heritage of Karnataka. Mysore: Geetha book house.

Muttanna, I., 1990. History of Karnataka. Mysore: Usha Publications.

Nagaraj, D., 1993. Flaming Feet - A Study of Dalit Movement in Karnataka. Bangalore: South Forum Press.

Nair, J., 1996. Memories of Underdevelopment: The Identities of Language in Contemporary Karnataka. Economic And Political Weekly, 42(21).

Panikkar, K. N., 1990. Culture and Conciseness in modern India: A historical perspective. Social Scientist, April, pp. 3-32.

Rao, G., 2012. Karnataka Ekikarana Itihasa. Bangalore: Navakarnataka publications.

Rao, R. K., 2010. Karnataka Unification: A Political Interpretation. Hampi: Kannada University.

Rice, B. Epigraphia Carnatica Vol. II, Intra, Mysore and Koorg from the Inscriptions. Government of India.

Sathyan, S. B., 1965. Mysore State Gazetteers: Coorg District. Bangalore: Director of Print., Stationary and Publications.

Sheik, A. E., 1997. Karnataka Charitre. Hampi: Kannada University.

Srinivas, M., \& Narayan, S., 1946. Karnataka Ekikarana. 
Srinivasa, I. B., 1924. Karnataka Handbook. Mysore: Karnataka Pradesh Congress Committee.

The Backward Classes Commission Report Vol 1, 1956. New Delhi: Government of India.

\section{News papers:}

Deccan Herald. English daily from Bangalore. Karnataka.

Samyuktha Karnataka: Kannada daily from Hubli. Karnataka.

Taruna Karnataka: Kannada daily from Hubli. Karnataka.

The Hindu. English daily from Chennai, Tamilnadu.

\section{About Authors}

\section{Mahesh RAMASWAMY}

He is working as Prof and Head, Department of History, D V S Evening Collage, Shimoga, Karnataka State. He holds M.A. in History and has submitted PhD thesis to Benares Hindu University, Varanasi on "Socio Economic Changes in Karnataka 1956-2015". He has worked as a Principal in a degree collage for more than 10 years and was a member of Academic council of Kuvempu University, Shimoga, Karnataka State. He also worked in North East Africa under UNDP Scheme. He has coordinated a national seminar on "Nurturing Human values Among Children". His recent publications include: "Talent Management in Higher Education: A Case Study of Government First Grade Collage Shimoga ' in AIIJRMSST Special issue Vol 1 No 2 ISSN 2320-2939 (Print) and "Study of Vijayanagar coins in AIIJRMSST" Vol 9 No 9 Jan 2015 ISSN 2320-2939 (Print) and ISSN 2320-2793 (Online). He has authored a biography on first doctor of Shimoga city who never charged his patients for the service rendered which is under print. maheshramaswamy@gmail.com

\section{Asha. S}

Ms Asha. $\mathrm{S}$ is working as a Guest Faculty at Government Degree Collage in Shimoga. She holds MBA degree from Visvesvaraya Technological University. She has teaching experience of 5 years in a degree collage. Before that she has worked as an administrator in a school for 5 years which imparts value based education for children and served as the trustee of it as well. She jointly co ordinated a national seminar on "Nurturing Human values Among Children". She has authored articles on "Viral Marketing" and "Subprime Crisis" in JNNCE Magazine. Her recent publications include "Talent Management in Higher Education: A Case Study of Government First Grade Collage Shimoga ' in AIIJRMSST Special issue Vol 1 No 2 ISSN 2320-2939 (Print) and "Study of Vijayanagar coins in AIIJRMSST" Vol 9 No 9 Jan 2015 ISSN 2320-2939 (Print) and ISSN 2320-2793 (Online). ashamahesh2000@gmail.com 